\title{
Polymerization of Methylpentynes by Transition Metal Catalysts: Monomer Structure, Reactivity, and Polymer Properties*
}

\author{
Toshio MASUdA, Masaaki KaWASAKI, Yoshimichi OKanO, \\ and Toshinobu HIGASHIMURA \\ Department of Polymer Chemistry, Kyoto University, \\ Kyoto 606, Japan.
}

(Received December 25, 1981)

\begin{abstract}
Polymerization of three methylpentynes, that is, 4-methyl-1-pentyne, 3-methyl-1pentyne and 4-methyl-2-pentyne by $\mathrm{MCl}_{n}, \mathrm{MCl}_{n} \cdot \mathrm{Ph}_{4} \mathrm{Sn}$, or $\mathrm{M}(\mathrm{CO})_{6}-\mathrm{CCl}_{4}-h v(\mathrm{M}=\mathrm{Mo}$, W) provided in high yields polymers, whose molecular weights were around $1 \times 10^{4}$. While Ziegler-type catalysts could polymerize only prim- and s-alkylacetylenes, Mo- or W-based catalysts proved to polymerize all seven isomers of 1-hexyne, $\left(\mathrm{C}_{6}\right.$ alkynes $)$ including the methylpentynes. Isomerization did not occur during the polymerization. The color and softening point of the seven polymers were well correlated to the number and branching of side chain. These polymers generally showed low electrical conductivities $\left(\sim 10^{-18} \mathrm{ohm}^{-1} \mathrm{~cm}^{-1}\right)$ and unpaired electron densities $\left(\leq 10^{16} \mathrm{spin}^{-1}\right)$.

KEY WORDS Coordination Polymerization / Transition Metal Catalyst / Tungsten Hexachloride / Molybdenum Pentachloride / Methylpentyne / Aliphatic Acetylene / Monomer Reactivity / Electrical Conductivity / Unpaired Electron Density /
\end{abstract}

Ziegler-type catalysts are known to bring about the polymerization of acetylenes. However, Zieglertype catalysts can give high molecular weight polymers only from sterically unhindered acetylenes such as acetylene itself ${ }^{2}$ and linear 1-alkynes. ${ }^{3}$

We have found that molybdenum (Mo) and tungsten (W) based catalysts polymerize rather sterically hindered acetylenes like $t$-butylacetylene, ${ }^{4}$ 2-alkynes ${ }^{1}$ and sym-dialkylacetylenes, ${ }^{5}$ and extremely high polymers $\left(M_{w} 10^{5}-10^{6}\right)$ are formed from $t$-butylacetylene and 2-alkynes. On the other hand, the polymerization of 1-hexyne by Mo- and W-based catalysts affords not only low molecular weight polymers $\left(M_{n} \sim 4000\right)$ but also cyclic trimers. ${ }^{6}$ In this way, both the position of triple bond and the branching of substituent(s) in an acetylenic monomer greatly affect polymerizability and polymer molecular weight. This will be further clarified by a study of the polymerization of methylpentynes which have the identical molecular for- mula, $\mathrm{C}_{6} \mathrm{H}_{10}$.

The present paper deals with the polymerization of three methylpentynes (4-methyl-1-pentyne, 3methyl-1-pentyne and 4-methyl-2-pentyne), and presents a comparison of polymerizabilities of all seven isomers of 1-hexyne (referred to as $C_{6}$ alkynes below). Three kinds of catalysts exploited by us are used: i) $\mathrm{MoCl}_{5}, \mathrm{WCl}_{6}$, which are effective for monosubstituted acetylenes, ${ }^{4,6}$ ii) $\mathrm{MoCl}_{5} \cdot \mathrm{Ph}_{4} \mathrm{Sn}$ (1:1), $\mathrm{WCl}_{6} \cdot \mathrm{Ph}_{4} \mathrm{Sn}(1: 1)$, which show high activity for disubstituted acetylenes, ${ }^{1,5}$ iii) $\mathrm{Mo}(\mathrm{CO})_{6}$ $\mathrm{CCl}_{4}-h v, \mathrm{~W}(\mathrm{CO})_{6}-\mathrm{CCl}_{4}-h v$, which produce very high polymers [e.g., $\operatorname{poly}(t$-butylacetylene $)]^{7}$ Two Ziegler-type catalysts are also employed for comparison: $\mathrm{Fe}(\mathrm{acac})_{3} \cdot 3 \mathrm{Et}_{3} \mathrm{Al}, \mathrm{Ti}(\mathrm{OnBu})_{4}$. $4 \mathrm{Et}_{3} \mathrm{Al}$, which have been successfully used for the polymerizations of prim- or $s$-alkylacetylenes ${ }^{3}$ and acetylene, ${ }^{2}$ respectively. Further, the structure and properties of the polymers formed from $\mathrm{C}_{6}$ alkynes are discussed in detail.

\footnotetext{
* Polymerization of Aliphatic Acetylenes. IV. For Part III, see ref 1.
} 


\section{EXPERIMENTAL}

\section{Materials}

4-Methyl-1-pentyne and 3-methyl-1-pentyne were purchased from Farchan Labs, USA. 4-Methyl-2pentyne was prepared from 4-methyl-2-pentanone by chlorination and subsequent dehydrochlorination with a slight modification of the synthesis of $t$-butylacetylene. ${ }^{8,9}$ Overall yield $55 \%$. These monomers were distilled from calcium hydride at atmospheric pressure. Catalysts were commercially obtained and used without further purification. Solvents for polymerization were purified by standard methods, thoroughly dried, and deaerated before use.

\section{Procedures}

The polymerization procedure is the same as described before. ${ }^{1,4}$ The number-average molecular weights of polymers were determined on a Hitachi 117 molecular weight apparatus. Combustion analysis was performed by the laboratory for organic elemental microanalysis, Kyoto University. ${ }^{1} \mathrm{H}$ and ${ }^{13} \mathrm{C}$ NMR spectra were recorded on a JEOL FX90Q spectrometer. Unpaired electron densities were determined at room temperature with a JEOL PE-2X
ESR spectrometer, using 1,1-diphenyl-2-picrylhydrazyl as a reference. Electrical conductivities were measured as described elsewhere. ${ }^{10}$

\section{RESULTS AND DISCUSSION}

\section{Polymerization of 4-Methyl-1-pentyne}

4-Methyl-1-pentyne ( $i$-butylacetylene) is a primalkylacetylene like 1-hexyne. The polymerization of 4-methyl-1-pentyne by various catalysts are shown in Table I (No. 1-8). The polymerizations by $\mathrm{MoCl}_{5}$ and $\mathrm{WCl}_{6}$ in toluene proceeded in high conversions. The addition of $\mathrm{Ph}_{4} \mathrm{Sn}$ as cocatalyst hardly affected the final conversions after $24 \mathrm{~h}$ polymerization, although the initial rate may have been accelerated. The metal carbonyl catalysts brought about polymerization in a similar manner. It can be said that W-based catalysts generally show higher activity than corresponding Mo-based catalysts. Two Ziegler-type catalysts also polymerized this monomer.

Table I also includes the results of polymerization in various solvents carried out with the $\mathrm{WCl}_{6} \cdot \mathrm{Ph}_{4} \mathrm{Sn}$ catalyst (No. 9-14). Not only hydrocarbons but also halogenated hydrocarbons and ethers were similarly useful as solvents.

Table I. Polymerization of 4-methyl-1-pentyne ${ }^{a}$

\begin{tabular}{|c|c|c|c|c|c|}
\hline No. & Catalyst & Solvent & $\begin{array}{c}\text { Convn } \\
\frac{\%}{\%}\end{array}$ & $\frac{\text { Yield }^{\mathrm{b}}}{\%}$ & $M_{n}$ \\
\hline 1 & $\mathrm{MoCl}_{5}$ & Toluene & $68^{c}$ & 32 & 4600 \\
\hline 2 & $\mathrm{WCl}_{6}$ & Toluene & $100^{\mathrm{d}}$ & 73 & 4900 \\
\hline 3 & $\mathrm{MoCl}_{5} \cdot \mathrm{Ph}_{4} \mathrm{Sn}$ & Toluene & 40 & 22 & 4700 \\
\hline 4 & $\mathrm{WCl}_{6} \cdot \mathrm{Ph}_{4} \mathrm{Sn}$ & Toluene & 100 & 77 & 5300 \\
\hline 5 & $\mathrm{Mo}(\mathrm{CO})_{6}-\mathrm{CCl}_{4}-h v^{\mathrm{e}}$ & $\mathrm{CCl}_{4}$ & 58 & 5 & - \\
\hline 6 & $\mathrm{~W}(\mathrm{CO})_{6}-\mathrm{CCl}_{4}-h v^{\mathrm{e}}$ & $\mathrm{CCl}_{4}$ & 100 & 85 & 8100 \\
\hline 7 & $\mathrm{Fe}(\mathrm{acac})_{3} \cdot 3 \mathrm{Et}_{3} \mathrm{Al}$ & Toluene & - & 33 & 3500 \\
\hline 8 & $\mathrm{Ti}(\mathrm{O} n \mathrm{Bu})_{4} \cdot 4 \mathrm{Et}_{3} \mathrm{Al}$ & Toluene & - & 38 & 8400 \\
\hline 9 & $\mathrm{WCl}_{6} \cdot \mathrm{Ph}_{4} \mathrm{Sn}$ & Cyclohexane & 100 & 78 & 5700 \\
\hline 10 & , & Cyclohexane & 100 & 80 & 7500 \\
\hline 11 & $" \prime$ & $\mathrm{CCl}_{4}$ & 100 & 77 & 5300 \\
\hline 12 & $" \prime$ & $\left(\mathrm{CH}_{2} \mathrm{Cl}\right)_{2}$ & 76 & 38 & 3500 \\
\hline 13 & $" \prime$ & 1,4-Dioxane & 100 & 89 & 10000 \\
\hline 14 & $" \prime$ & Anisole & 89 & 59 & 5300 \\
\hline
\end{tabular}

a Polymerized at $30^{\circ} \mathrm{C}$ for $24 \mathrm{~h}:[\mathrm{M}]_{0}=1.0 \mathrm{M}$, [Cat $]=20 \mathrm{mM}$.

b Yield of methanol-insoluble polymers.

c Methanol-soluble products: linear oligomer, 27\%; 1,2,4-cyclotrimer, 6\%; 1,3,5-cyclotrimer 3\%.

d Methanol-soluble products: linear oligomer, 19\%, 1,2,4-cyclotrimer, 4\%, 1,3,5-cyclotrimer, 4\%.

e Irradiated with UV light at $30^{\circ} \mathrm{C}$ for $1 \mathrm{~h}$. 
The molecular weights of methanol-insoluble polymers were not very high $\left(M_{n} 3500-10000\right)$, and methanol-soluble products (linear oligomer and cyclic trimers, each evaluated by liquid chromatography and ${ }^{1} \mathrm{H}$ NMR) were obtained in considerable amounts. The $\mathrm{W}(\mathrm{CO})_{6}-\mathrm{CCl}_{4}-h v$ catalyst was more favorable to the formation of high polymer than was $\mathrm{WCl}_{6}$. Polymer molecular weight was the highest when 1,4-dioxane was used as solvent in the $\mathrm{WCl}_{6} \cdot \mathrm{Ph}_{4} \mathrm{Sn}$-catalyzed polymerization; the same tendency is also observed in the polymerization of phenylacetylene. ${ }^{11}$

The analytical and spectral data of poly(4methyl-1-pentyne) (sample from Table I, No. 4) are as follows: Anal. Calcd for $\left(\mathrm{C}_{6} \mathrm{H}_{10}\right)_{n}: \mathrm{C}, 87.73 \% ; \mathrm{H}$, $12.27 \%$. Found: C, $87.21 \%$; H, 12.53\%. IR 2950 (s), $2900(\mathrm{~s}), 2850(\mathrm{~s}), 1650-1580(\mathrm{w}), 1460(\mathrm{~m}), 1380$ $(\mathrm{m}), 1360(\mathrm{~m}), 1160(\mathrm{~m}), 1090(\mathrm{w}), 910(\mathrm{w}), 890(\mathrm{w})$, and $800 \mathrm{~cm}^{-1}(\mathrm{w}) .{ }^{1} \mathrm{H}$ NMR $\left(\mathrm{CDCl}_{3}\right) \delta 6.5-5.0(\mathrm{br}$ $\mathrm{s}, 1,-\mathrm{CH}=), 1.96\left(\mathrm{~s}, 3,=\mathrm{CCH}_{2} \mathrm{CH}\right)$, and $0.86 \mathrm{ppm}$ $\left(\mathrm{s}, 6,2 \mathrm{CH}_{3}\right) \cdot{ }^{13} \mathrm{C} \mathrm{NMR}\left(\mathrm{CDCl}_{3}\right) \delta 138.6\left(\mathrm{C}_{2}\right), 127.8$ $\left(\mathrm{C}_{1}\right), 43.4\left(\mathrm{C}_{3}\right), 27.3\left(\mathrm{C}_{4}\right)$, and $22.7 \mathrm{ppm}\left(\mathrm{C}_{5}, \mathrm{Me}\right)$. $\mathrm{UV}_{\text {max }}$ (cyclohexane) $250 \mathrm{~nm}(\varepsilon 1900)$.

The IR spectrum shows a band due to conjugated double bonds at $1650-1580 \mathrm{~cm}^{-1}$, and all the signals in ${ }^{1} \mathrm{H}$ and ${ }^{13} \mathrm{C}$ NMR spectra are readily assigned. Thus these spectral data support the polymer structure formed without isomerization, that is, $(\mathrm{CH}=\mathrm{CiBu})_{h}$. This polymer has the form of yellow powder, and was soluble in low-polarity solvents such as $n$-hexane, benzene, carbon tetrachloride and chloroform while insoluble in polar solvents like acetone, ethyl acetate, acetonitrile and dimethyl sulfoxide.

\section{Polymerization of 3-Methyl-1-pentyne}

The polymerization of 3-methyl-1-pentyne ( $s$ butylacetylene), a terminal alkyne bearing a secondary alkyl group, was examined with various catalysts and solvents. As can be seen from Table II, this monomer was polymerized in high yields by both $\mathrm{MoCl}_{5}$ and $\mathrm{WCl}_{6}$ by themselves. It is noted that, in this case, the catalytic activity of $\mathrm{MoCl}_{5}$ is comparable to or somewhat greater than that of $\mathrm{WCl}_{6}$. Like the polymerization of 4-methyl-1pentyne, $\mathrm{Ph}_{4} \mathrm{Sn}$ had practically no influence on the final conversions and polymer yields, all of Mo-, Wbased and Ziegler-type catalysts were effective, and polymerization occurred in a variety of solvents.

The molecular weights of poly(3-methyl-1pentyne) obtained with the Mo- and W-based catalysts spanned from 3000 to 14000 . Further, molecular weight reached 22000 at $0^{\circ} \mathrm{C}$ with $\mathrm{MoCl}_{5} \cdot \mathrm{Ph}_{4} \mathrm{Sn}$ in toluene. It should be noted that $\mathrm{Fe}(\mathrm{acac})_{3} \cdot 3 \mathrm{Et}_{3} \mathrm{Al}$ afforded a polymer having even higher molecular weight.

Table II. Polymerization of 3-methyl-1-pentyne ${ }^{a}$

\begin{tabular}{|c|c|c|c|c|c|}
\hline No. & Catalyst & Solvent & $\frac{\text { Convn }}{\%}$ & $\frac{\text { Yield }^{b}}{\%}$ & $M_{n}$ \\
\hline 1 & $\mathrm{MoCl}_{5}$ & Toluene & 100 & 92 & 9900 \\
\hline 2 & $\mathrm{WCl}_{6}$ & Toluene & 96 & 79 & 5500 \\
\hline 3 & $\mathrm{MoCl}_{5} \cdot \mathrm{Ph}_{4} \mathrm{Sn}$ & Toluene & 100 & 92 & 13000 \\
\hline 4 & $\mathrm{WCl}_{6} \cdot \mathrm{Ph}_{4} \mathrm{Sn}$ & Toluene & 100 & 85 & 5300 \\
\hline 5 & $\mathrm{Mo}(\mathrm{CO})_{6}-\mathrm{CCl}_{4}-h v^{\mathrm{c}}$ & $\mathrm{CCl}_{4}$ & 24 & 22 & 3300 \\
\hline 6 & $\mathrm{~W}(\mathrm{CO})_{6}-\mathrm{CCl}_{4}-h v^{\mathrm{c}}$ & $\mathrm{CCl}_{4}$ & 100 & $\sim 100$ & 13000 \\
\hline 7 & $\mathrm{Fe}(\mathrm{acac})_{3} \cdot 3 \mathrm{Et}_{3} \mathrm{Al}$ & Toluene & - & 96 & 27000 \\
\hline 8 & $\mathrm{Ti}(\mathrm{O} n \mathrm{Bu})_{4} \cdot 4 \mathrm{Et}_{3} \mathrm{Al}$ & Toluene & - & 14 & - \\
\hline 9 & $\mathrm{MoCl}_{5} \cdot \mathrm{Ph}_{4} \mathrm{Sn}$ & Cyclohexane & 100 & $\sim 100$ & 14000 \\
\hline 10 & " & Cyclohexene & 71 & 60 & 9300 \\
\hline 11 & " & $\mathrm{CCl}_{4}$ & 100 & 93 & 9200 \\
\hline 12 & $\prime \prime$ & $\left(\mathrm{CH}_{2} \mathrm{Cl}\right)_{2}$ & 100 & 87 & 9700 \\
\hline 13 & $\prime \prime$ & 1,4-Dioxane & 98 & 80 & 14000 \\
\hline 14 & $\prime \prime$ & Anisole & 100 & 85 & 11000 \\
\hline
\end{tabular}

a Polymerized at $30^{\circ} \mathrm{C}$ for $24 \mathrm{~h}:[\mathrm{M}]_{0}=1.0 \mathrm{M}$, [Cat $]=20 \mathrm{mM}$.

b Yield of methanol-insoluble polymers.

c Irradiated with UV light at $30^{\circ} \mathrm{C}$ for $1 \mathrm{~h}$. 
The analytical and spectral data of poly(3methyl-1-pentyne) (sample from Table II, No. 4) are: Anal. Calcd for $\left(\mathrm{C}_{6} \mathrm{H}_{10}\right)_{n}: \mathrm{C}, 87.73 \% ; \mathrm{H}$, $12.27 \%$. Found: C, $87.48 \%$; H, 12.32\%. IR 2950 (s), 2900 (s), 2850 (s), 1650-1580 (w), $1460(\mathrm{~m}), 1370$ (m), $1010(\mathrm{w}), 950(\mathrm{w}), 880(\mathrm{w})$, and $770 \mathrm{~cm}^{-1}(\mathrm{w})$. ${ }^{1} \mathrm{H}$ NMR $\left(\mathrm{CDCl}_{3}\right) \delta 6.3-5.6(\mathrm{br} \mathrm{s}, 1,-\mathrm{CH}=), 2.92$ (s, 1, =CCH), $1.36\left(\mathrm{~s}, 2,-\mathrm{CH}_{2}-\right.$ ), and $0.91 \mathrm{ppm}(\mathrm{s}$, $\left.6,2 \mathrm{CH}_{3}\right) \cdot{ }^{13} \mathrm{C}$ NMR $\left(\mathrm{CDCl}_{3}\right) \delta 143.9\left(\mathrm{C}_{2}\right), 126.9$ $\left(\mathrm{C}_{1}\right), 37.1\left(\mathrm{C}_{3}\right), 28.7\left(\mathrm{C}_{4}\right), 20.0(\mathrm{Me})$, and $12.4 \mathrm{ppm}$ $\left(C_{5}\right) . U_{\text {max }}$ (cyclohexane) $296 \mathrm{~nm}(\varepsilon 2700)$.

Based on the above data, poly(3-methyl-1pentyne) is concluded to have the expected conjugated double bonds structure, $(\mathrm{CH}=\mathrm{Cs} \mathrm{Bu})_{n}$. This polymer is in the form of light yellow powder, and showed solubility similar to that of poly(4methyl-1-pentyne) (vide supra).

\section{Polymerization of 4-Methyl-2-pentyne}

4-Methyl-2-pentyne is a disubstituted acetylene and the most sterically hindered among the $\mathrm{C}_{6}$ alkynes. Since this monomer was less reactive than 4-methyl-1-pentyne and 3-methyl-1-pentyne, the polymerization was carried out at higher temperature and catalyst concentration $\left(60^{\circ} \mathrm{C}\right.$, [Cat] $=$ $30 \mathrm{mM}$ ). As a consequence, only $\mathrm{WCl}_{6} \cdot \mathrm{Ph}_{4} \mathrm{Sn}$ afforded a methanol-insoluble polymer among eight catalysts examined (see Table III). It is not clear at present why $\mathrm{MoCl}_{5} \cdot \mathrm{Ph}_{4} \mathrm{Sn}$ was ineffective. The effect of solvent on polymer yield should also be noted. For instance, no polymer was formed in ethers in the $\mathrm{WCl}_{6} \cdot \mathrm{Ph}_{4} \mathrm{Sn}$-catalyzed polymerization. The polymer molecular weights were about $1 \times 10^{4}$ or lower.

The analytical and spectral data of poly(4methyl-2-pentyne) (sample from Table III, No. 4): Anal. Calcd for $\left(\mathrm{C}_{6} \mathrm{H}_{10}\right)_{n}: \mathrm{C}, 87.73 \% ; \mathrm{H}, 12.27 \%$. Found: C, $87.16 \% ; \mathrm{H}, 12.34 \%$. IR 2950 (s), 2900 (s), $2850(\mathrm{~s}), 1650-1580(\mathrm{w}), 1470(\mathrm{~m}), 1380(\mathrm{~m}), 1360$ $(\mathrm{m}), 1090(\mathrm{~m}), 1030(\mathrm{~m}), 1010(\mathrm{~m}), 800(\mathrm{w})$, and 700 $\mathrm{cm}^{-1}(\mathrm{w}) .{ }^{1} \mathrm{H}$ NMR $\left(\mathrm{CDCl}_{3}\right) \delta 2.88(\mathrm{~s}, 1, \mathrm{CH}), 1.77$ (s, 3, $\left.-\mathrm{C}\left(\mathrm{CH}_{3}\right)=\right)$, and $1.03 \mathrm{ppm}\left(\mathrm{s}, 6,-\mathrm{C}\left(\mathrm{CH}_{3}\right)_{2}\right)$. ${ }^{13} \mathrm{C}$ NMR $\left(\mathrm{CDCl}_{3}\right) \delta 143.8\left(\mathrm{C}_{3}\right), 130.5\left(\mathrm{C}_{2}\right), 33.0$ $\left(\mathrm{C}_{4}\right)$, and $22.7 \mathrm{ppm}\left(\mathrm{C}_{1}, \mathrm{C}_{5}, \mathrm{Me}\right)$. $\mathrm{UV}_{\max }$ (cyclohexane) $283 \mathrm{~nm}(\varepsilon 610)$.

These data indicate that the polymer has the expected structure, $(\mathrm{CMe}=\mathrm{CiPr})_{n}$ from which it is concluded that the monomer is not isomerized to 4methyl-1-pentyne in the course of polymerization. Poly(4-methyl-2-pentyne) is a white powder, and also dissolved completely in nonpolar solvents like benzene.

\section{Monomer Reactivity and Catalyst Activity}

Table IV summarizes the polymerizability of all seven $\mathrm{C}_{6}$ alkynes and the activity of Mo-, W-based

Table III. Polymerization of 4-methyl-2-pentyne ${ }^{a}$

\begin{tabular}{|c|c|c|c|c|c|}
\hline No. & Catalyst & Solvent & $\frac{\text { Convn }}{\%}$ & $\begin{array}{c}\text { Yield }^{\mathbf{b}} \\
\% \frac{\mathrm{o}}{\mathrm{s}}\end{array}$ & $M_{n}$ \\
\hline 1 & $\mathrm{MoCl}_{5}$ & Toluene & 7 & 0 & - \\
\hline 2 & $\mathrm{WCl}_{6}$ & Toluene & 13 & $\sim 0$ & - \\
\hline 3 & $\mathrm{MoCl}_{5} \cdot \mathrm{Ph}_{4} \mathrm{Sn}$ & Toluene & 0 & 0 & - \\
\hline 4 & $\mathrm{WCl}_{6} \cdot \mathrm{Ph}_{4} \mathrm{Sn}$ & Toluene & 85 & 73 & 8400 \\
\hline 5 & $\mathrm{Mo}(\mathrm{CO})_{6}-\mathrm{CCl}_{4}-h v^{\mathrm{c}}$ & $\mathrm{CCl}_{4}$ & 0 & 0 & - \\
\hline 6 & $\mathrm{~W}(\mathrm{CO})_{6}-\mathrm{CCl}_{4}-h v^{\mathrm{c}}$ & $\mathrm{CCl}_{4}$ & 0 & 0 & - \\
\hline 7 & $\mathrm{Fe}(\mathrm{acac})_{3} \cdot 3 \mathrm{Et}_{3} \mathrm{Al}$ & Toluene & - & 0 & - \\
\hline 8 & $\mathrm{Ti}(\mathrm{O} n \mathrm{Bu})_{4} \cdot 4 \mathrm{Et}_{3} \mathrm{Al}$ & Toluene & - & 0 & - \\
\hline 9 & $\mathrm{WCl}_{6} \cdot \mathrm{Ph}_{4} \mathrm{Sn}$ & Cyclohexane & 78 & 57 & 10000 \\
\hline 10 & , , & Cyclohexene & 100 & $\sim 100$ & 11000 \\
\hline 11 & $\prime \prime$ & $\mathrm{CCl}_{4}$ & 47 & 35 & 5800 \\
\hline 12 & $" 1$ & $\left(\mathrm{CH}_{2} \mathrm{Cl}\right)_{2}$ & 40 & 19 & 3400 \\
\hline 13 & $\prime \prime$ & 1,4-Dioxane & 0 & 0 & - \\
\hline 14 & ", & Anisole & 0 & 0 & - \\
\hline
\end{tabular}

a Polymerized at $60^{\circ} \mathrm{C}$ for $24 \mathrm{~h}:[\mathrm{M}]_{0}=1.0 \mathrm{M}$, [Cat $]=30 \mathrm{mM}$.

b Yield of methanol-insoluble polymers.

c Irradiated with UV light at $30^{\circ} \mathrm{C}$ for $1 \mathrm{~h}$. 
Polymerization of Methylpentynes

Table IV. Monomer reactivity and catalyst activity in the polymerization of $\mathrm{C}_{6}$ alkynes ${ }^{\mathrm{a}}$

\begin{tabular}{|c|c|c|c|c|c|c|c|c|c|}
\hline $\begin{array}{c}\mathrm{C}_{6} \\
\text { alkyne }\end{array}$ & $\mathrm{MoCl}_{5}$ & $\mathrm{WCl}_{6}$ & $\begin{array}{l}\mathrm{MoCl}_{5} \\
\mathrm{Ph}_{4} \mathrm{Sn}\end{array}$ & $\begin{array}{l}\mathrm{WCl}_{6} \\
\mathrm{Ph}_{4} \mathrm{Sn}\end{array}$ & $\mathrm{Mo}(\mathrm{CO})_{6}$ & $\mathrm{~W}(\mathrm{CO})_{6}$ & $\begin{array}{c}\mathrm{Fe}\left(\mathrm{acac}_{)_{3}} \cdot\right. \\
\quad 3 \mathrm{Et}_{3} \mathrm{Al}\end{array}$ & $\begin{array}{c}\mathrm{Ti}(\mathrm{O} n \mathrm{Bu})_{4} \\
\quad 4 \mathrm{Et}_{3} \mathrm{Al}\end{array}$ & $\begin{array}{l}\text { Catalyst } \\
\text { activity }^{\mathbf{b}}\end{array}$ \\
\hline $\mathrm{C} \equiv \mathrm{C}-\mathrm{C}-\mathrm{C}-\mathrm{C}-\mathrm{C}$ & O & 0 & 0 & (a) & O & O & (0) & O & $\mathrm{W}>\mathrm{Mo}$ \\
\hline$\underset{\mathrm{C}}{\mathrm{C} \equiv \mathrm{C}-\mathrm{C}-\mathrm{C}-\mathrm{C}}$ & () & () & () & () & 0 & () & () & (a) & $\mathrm{W}>\mathrm{Mo}$ \\
\hline $\begin{array}{c}\mathrm{C} \equiv \mathrm{C}-\mathrm{C}-\mathrm{C}-\mathrm{C} \\
\mathrm{C} \\
\mathrm{C}\end{array}$ & (2) & (0) & (0) & () & () & () & (0) & 0 & $\mathrm{Mo} \simeq \mathrm{W}$ \\
\hline $\begin{array}{c}\mathrm{C} \equiv \underset{\mathrm{C}}{\mathrm{C}-\mathrm{C}-\mathrm{C}} \\
\mathrm{C}\end{array}$ & (2) & (0) & () & () & () & () & $x$ & $x$ & Mo $>$ W \\
\hline $\mathrm{C}-\mathrm{C} \equiv \mathrm{C}-\mathrm{C}-\mathrm{C}-\mathrm{C}$ & $x$ & $x$ & () & () & $\triangle$ & $x$ & $x$ & $x$ & Mo $>$ W \\
\hline 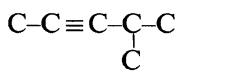 & $x$ & $x$ & $x$ & (2) & $x$ & $x$ & $x$ & $x$ & $\mathrm{~W} \gg \mathrm{Mo}$ \\
\hline $\mathrm{C}-\mathrm{C}-\mathrm{C} \equiv \mathrm{C}-\mathrm{C}-\mathrm{C}$ & $x$ & $x$ & $\triangle$ & (0) & $x$ & $x$ & $x$ & $x$ & $\mathrm{~W}>\mathrm{Mo}$ \\
\hline
\end{tabular}

Table V. ${ }^{13} \mathrm{C}$ NMR chemical shifts $(\delta)$ of $\mathrm{C}_{6}$ alkynes

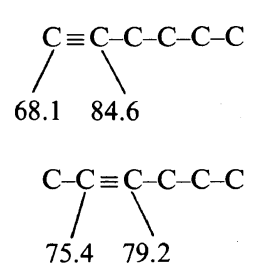<smiles>C=C(C(=O)O)C(C)(C)C</smiles><smiles>CC1=C2CC2CC1C</smiles>
$\begin{array}{ll}74.6 & 85.2\end{array}$

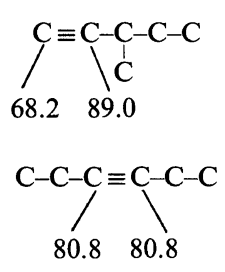

and Ziegler-type catalysts. Part of the data have been quoted from our previous studies. ${ }^{1,4-6}$ Conclusions from Table IV regarding monomer reactivity include: Disubstituted acetylenes are successfully polymerized by $\mathrm{WCl}_{6} \cdot \mathrm{Ph}_{4} \mathrm{Sn}$ and/or $\mathrm{MoCl}_{5} \cdot \mathrm{Ph}_{4} \mathrm{Sn}$. All monosubstituted acetylenes, including $t$-butylacetylene, can be polymerized by any Mo- and W-based catalysts. On the other hand, it is only prim-and $s$-alkylacetylenes that can be polymerized by Ziegler-type catalysts.

The following are pointed out concerning catalyst activity: Which of the Mo- and W-based catalysts is more active, depends on monomer; the rationale for this dependence, however, has not been found. Further, if $\mathrm{MoCl}_{5}\left(\cdot \mathrm{Ph}_{4} \mathrm{Sn}\right)$ is more active toward a monomer than is $\mathrm{WCl}_{6}\left(\cdot \mathrm{Ph}_{4} \mathrm{Sn}\right), \mathrm{Mo}(\mathrm{CO})_{6}$ tends to be more effective toward the same monomer than $\mathrm{W}(\mathrm{CO})_{6}$, and vice versa.

The ${ }^{13} \mathrm{C}$ NMR chemical shifts of acetylenic carbons of $\mathrm{C}_{6}$ alkynes, measured in $\mathrm{CDCl}_{3}$ solution $(10 \mathrm{v} / \mathrm{v} \%)$, are shown in Table V. Judging from these chemical shifts, the electron densities of acetylenic carbons vary significantly, depending on the kind of monomer. However, the polymerizability of these monomers cannot be interpreted in terms of the estimated electron densities, but is greatly affected 
Table VI. Molecular weight ${ }^{\mathrm{a}}$ and properties $^{\mathrm{b}}$ of the polymers from $\mathrm{C}_{6}$ alkynes

\begin{tabular}{|c|c|c|c|c|c|c|}
\hline Polymer & $M \times 10^{-3}$ & Color & $\mathrm{UV}^{\mathfrak{c}}$ & $\begin{array}{l}\text { Softening } \\
\text { point }\end{array}$ & $\begin{array}{c}\text { Conductivity } \\
\times 10^{18}\end{array}$ & $\begin{array}{c}\text { Unpaired electron } \\
\text { density } \times 10^{-15}\end{array}$ \\
\hline & & & $\mathrm{nm}$ & ${ }^{\circ} \mathrm{C}$ & $\mathrm{ohm}^{-1} \mathrm{~cm}^{-1}$ & $\operatorname{spin} \mathrm{g}^{-1}$ \\
\hline $\begin{aligned}-\mathrm{C}= & \mathrm{C}-\mathrm{I} \\
& \mathrm{C}-\mathrm{C}-\mathrm{C}-\mathrm{C}\end{aligned}$ & 4 & Orange & $<460$ & $<$ r.t. $^{\text {d }}$ & - & 23 \\
\hline $\begin{array}{c}(-\mathrm{C}=\underset{1}{\mathrm{C}})- \\
\mathrm{C} \\
\mathrm{C}-\mathrm{C}-\mathrm{C}\end{array}$ & 10 & Yellow & $<460$ & $\sim 110$ & 2 & 5 \\
\hline$(\mathrm{C}=\underset{\mathrm{I}}{\mathrm{C}} \mathrm{f}-\mathrm{C}-\mathrm{C}$ & 22 & $\begin{array}{l}\text { Light } \\
\text { Yellow }\end{array}$ & $<420$ & $\sim 130$ & 0.6 & 2 \\
\hline $\begin{array}{c}+\mathrm{C}=\underset{+}{\mathrm{C}+}+ \\
\mathrm{C}-\stackrel{+}{\mathrm{C}}-\mathrm{C} \\
\stackrel{C}{\mathrm{C}}\end{array}$ & 380 & White & $<330$ & $\sim 250$ & $<0.5$ & $<1$ \\
\hline $\begin{array}{l}+\mathrm{C}=\mathrm{C}+ \\
\stackrel{+}{\mathrm{C}} \stackrel{\mathrm{C}}{\mathrm{C}}-\mathrm{C}-\mathrm{C}\end{array}$ & $\sim 500$ & White & $<380$ & $\sim 230$ & $<0.5$ & $<1$ \\
\hline $\begin{array}{cc}+\mathrm{C}= & \mathrm{C}-\boldsymbol{f} \\
\mathrm{C} & \stackrel{\mathrm{C}}{\mathrm{C}}-\mathrm{C} \\
& \mathrm{C}\end{array}$ & 11 & White & $<340$ & $\sim 250$ & $<0.5$ & $<1$ \\
\hline 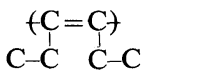 & $\begin{array}{l}\text { Partly } \\
\text { insol. }\end{array}$ & White & - & Infus. & $<0.5$ & $<1$ \\
\hline
\end{tabular}

${ }^{\text {a }}$ Highest molecular weights so far attained with Mo- and W-based catalysts.

b Polymer samples obtained with $\mathrm{WCl}_{6} \cdot \mathrm{Ph}_{4} \mathrm{Sn}$ in toluene.

c Measured in cyclohexane at $0.50 \mathrm{mM}$.

d Room temp.

by the steric factor of monomer. This suggests that the propagating species lacks ionic character.

\section{Molecular Weight and Properties of the Polymers from $C_{6}$ Alkynes}

Table VI lists the molecular weight and properties of the seven polymers from $\mathrm{C}_{6}$ alkynes. The following conclusions are possible from these data:

i) The molecular weights of poly(t-butylacetylene) and poly(2-hexyne) are prominently high. The formation of high-molecular-weight polymers only from rather sterically hindered acetylenes might be explained as follows: An adequate steric hindrance destroys the conjugation of the main chain including the propagating end, which results in the activation of the propagating end and/or in the protection of the polymer from degradation (see item (v) below).

ii) The colors correspond well to the absorption limits on the long wavelength side in the UV-visible spectra. The absorption limits appear to reflect the extent of coplanarity, and thus conjugation, of double bonds along the main chain.

iii) Poly(1-hexyne) is a viscous substance, while the other polymers are solid. The softening point of the polymers becomes higher with increased branching of side group(s), and is higher for disubstituted acetylenes than for monosubstituted ones. This result is well interpreted in terms of polymer chain stiffness.

iv) The electrical conductivities of compressedpellet samples were $10^{-18} \mathrm{ohm}^{-1} \mathrm{~cm}^{-1}$ or lower. When the semiconductivity $\left(10^{-9}-10^{-5} \mathrm{ohm}^{-1}\right.$ $\mathrm{cm}^{-1}$ ) of polyacetylene ${ }^{12}$ is taken into account, the presence of alkyl group(s) as side chain twists the main chain to greatly reduce conductivity.

v) Unpaired electron densities were $10^{16} \mathrm{spin}$ $\mathrm{g}^{-1}$ at the highest (peak-to-peak widths of ESR signals $8-10 \mathrm{G}$ ), and those of the polymers from $t$ butylacetylene and disubstituted acetylenes were undetectable $\left(<10^{15}\right.$ spin $\mathrm{g}^{-1}$, even if present). Polyacetylene shows unpaired electron densities as 
high as $10^{19}$ spin $\mathrm{g}^{-1}$ and unstable to air. ${ }^{13}$ Therefore, such low unpaired electron densities of the present polymers seem responsible for the relatively high stability of these polymers, especially of the spin-undetectable polymers.

Acknowledgements. We should like to thank Dr. Takashi Kawamura, Department of Hydrocarbon Chemistry, Kyoto University for kindly measuring the ESR spectra of the polymers. We also extend our appreciation to Mr. Yoshinori Kuwane for his assistance in monomer synthesis.

\section{REFERENCES}

1. T. Higashimura, Y.-X. Deng, and T. Masuda, Macromolecules, in press.

2. e.g., T. Ito, H. Shirakawa, and S. Ikeda, J. Polym. Sci., Polym. Chem. Ed., 12, 11 (1974).

3. e.g., F. Ciardelli, S. Lanzillo, and O. Pieroni,
Macromolecules, 7, 174 (1974).

4. T. Masuda, Y. Okano, Y. Kuwane, and T. Higashimura, Polym. J., 12, 907 (1980).

5. T. Masuda, Y. Kuwane, and T. Higashimura, Polym. J., 13, 301 (1981).

6. Y.-X. Deng, T. Takahashi, T. Masuda, and T. Higashimura, to be published.

7. T. Masuda, Y. Kuwane, K. Yamamoto, and T. Higashimura, Polym. Bull., 2, 823 (1980).

8. P. D. Bartlett and L. J. Rosen, J. Am. Chem. Soc., 64, 543 (1942).

9. P. J. Kocienski, J. Org. Chem., 39, 3285 (1974).

10. Y. Kuwane, T. Masuda, and T. Higashimura, Polym. J., 12, 387 (1980).

11. T. Masuda, T. Takahashi, K. Yamamoto, and T. Higashimura, J. Polym. Sci., Polym. Chem. Ed., in press.

12. H. Shirakawa, T. Itoh, and S. Ikeda, Makromol. Chem., 179, 1565 (1978).

13. e.g., A. Snow, P. Brant, D. Weber, and N.-L. Yang, J. Polym. Sci., Polym. Lett. Ed., 17, 263 (1979). 